\title{
ANALIZA SKŁADOWYCH WARTOŚCI ZABYTKOWEGO ZESPOŁU MIEJSKIEGO - PODSTAWA PROGRAMÓW I PLANÓW KONSERWATORSKICH
}

\section{SZMYGIN Bogusław ${ }^{1}$}

${ }^{1}$ prof. dr. hab. inż. Bogusław Szmygin Politechnika Lubelska https://orcid.org/0000-0003-0629-4495

ABSTRAKT: Celem Najbardziej złożonym problemem w ochronie zabytków jest ochrona historycznych miast. Zasadniczym problemem jest konieczność pogodzenia wymagań konserwatorskich(ograniczeniaprzekształceń)znarastającymipotrzebamimodernizacyjnymi. Miasto historyczne musi się modernizować, a więc konserwatorzy muszą określić przedmiot, formę i granice przekształceń. Konieczne jest zatem opracowanie metodologii, która pozwoli powiązać zabytkowe wartości zespołu z ich materialną reprezentacją. Dzięki temu będzie możliwe określenie elementów podlegających ochronie oraz elementów, które mogą być przekształcane.

Metodologia określania materialnej reprezentacji zabytkowych wartości została pokazana na przykładzie historycznego centrum Krakowa wpisanego na Listę Światowego Dziedzictwa UNESCO. Metodologia określania wartości (tzw. SMART VALUE) została wykorzystana w opracowaniu Planu Zarządzania Krakowa. Metodologia może być wykorzystana jako narządzie pomocne w zarządzaniu różnych grup zabytków, w szczególności o znaczącej wartości (przede wszystkim uznanych za Pomniki Historii lub dobra Światowego Dziedzictwa).

SŁOWA KLUCZOWE: miasta historyczne, wartościowanie zabytków, atrybuty wartości 
Współczesne pojęcie zabytku jest tak szerokie, że duża część środowiska kulturowego historycznych obiektów, zespołów, obszarów - jest przedmiotem ochrony konserwatorskiej. Wynika $\mathrm{z}$ tego wiele zadań i problemów, gdyż na całe środowisko kulturowe wywierana jest coraz większa presja modernizacyjna. Podlegają jej oczywiście również zabytki. Konserwatorzy stają więc przed coraz trudniejszym problemem pogodzenia potrzeb modernizacyjnych z ograniczeniami wynikającymi z ochrony zabytkowych wartości.

Najbardziej złożonym problemem w ochronie zabytków jest ochrona zabytkowych miast. Wynika to $\mathrm{z}$ faktu, że w historycznym zespole miejskim naitrudniej jest realizować jednocześnie dwa przeciwstawne procesy. Pierwszy proces polega na chronieniu składowych zespołu przed zmianami, zachowaniu ich $\mathrm{w}$ postaci ukształtowanej w przeszłości. Drugi proces polega na adaptacji i przekształcaniu tych składowych do potrzeb związanych ze współczesnym funkcjonowaniem miejskiego zespołu. To właśnie wielość i różnorodność funkcji, które musi realizować żyjący organizm miejski sprawia, że tak trudne jest pogodzenie procesu ochrony i procesu modernizacji. W praktyce bowiem wszystkie funkcje, które co najmniej w pewnym zakresie musi zapewniać współczesne miasto - mieszkalne, handel, usługi, edukacja, komunikacja, transport, wypoczynek, sport, rozrywka, zieleń - powinny być realizowane w innych standardach, niż na to pozwala zabudowa i przestrzeń staromiejska.

Nieusuwalny konflikt sprawia, że mieszkańcy i władze chronionych zespołów staromiejskich domagają się ograniczenia konserwatorskich restrykcji. W praktyce oczekuje się, że restrykcje będą miały charakter punktowy, będą ograniczone do najcenniejszych obiektów pełniących funkcjepubliczne, należących do podmiotów publicznych ifinansowanych zpublicznych środków. W stosunku do pozostałych obiektów oczekuje się ograniczenia wymagań konserwatorskich do wybranych elementów (na przykład elewacji), tym samym pozostałe elementy i przestrzeń będzie można dostosowywać do współczesnych potrzeb i standardów użytkowych. Zakłada się więc, że historyczna zabudowa i przestrzeń mogą być w istotnym zakresie przekształcane.

Ingerencjei przekształcenia zabytków w tradycyjnej teorii konserwatorskiej - obowiązującej przez większość XX wieku, były oceniane negatywnie i minimalizowane. Jednak presja modernizacyjna, najintensywniejsza w dużych historycznych miastach o znaczącej wartości, doprowadziła do zmiany podejścia. Międzynarodowa dyskusja o zagrożeniach związanych z budową kompleksu wysokich budynków w pobliżu historycznego centrum Wiednia doprowadziła do przejęcia w Vienna Memmorandum (2005), a potem Recommendation on Historic Cultural Landscape (tzw. Rekomendacji HUL) $)^{1}$. Dokument ten, przyjęty w 2011 roku przez Zgromadzenie Generalne UNESCO, usankcjonował podejście do miast historycznych akceptujące proces ich przekształceń, dostosowanie do współczesnych funkcji, szerokie uwzględnienie potrzeb wszystkich grup interesariuszy ${ }^{2}$. Podejście do miast historycznych przedstawione w Rekomendacji HUL zostało

1 Okoliczności powstania i charakterystykę treści Rekomendacji HUL omawia publikacja: Bandarin F., van Oers R., The Historic Urban Landscape. Managing Heritage in an Urban Century, Wiley-Blackwell, 2012

2 Dokumentem formalizującym rolę interesariuszy w relacjach z dziedzictwem jest konwencja przyjęta przez Rade Europy (Council of Europe Treaty Series - No. 199) Council of Europe Framework Convention on the Value of Cultural Heritage for Society (Faro,27.X.2005); http://conventions.coe.int/Treaty/EN/Treaties/Html/199.html 
przyjęte również w stosunku do zespołów wpisanych na Listę Światowego Dziedzictwa - to samym stało się elementem nowego paradygmatu tworzonego w ochronie dziedzictwa ${ }^{3}$.

Uchwalone przez międzynarodową społeczność konserwatorską założenia wymagają opracowania na poziomie operacyjnym. Jest to obecnie problem do opracowania w ramach rozwoju teorii konserwatorskiej. Jest to zadanie skomplikowane, gdyż wymaga stworzenia metodologii umożliwiającej analizę zabytku. W praktyce oznacza to sprowadzenie zabytku do uproszczonego modelu, który można analizować ze względu na przyjęte parametry.

Stworzenie modelu zabytku jest tak trudne, gdyż trzeba uwzględnić szereg zmieniających się aspektów materialnych i niematerialnych, które różnie są oceniane przez poszczególnych interesariuszy. Problem jest niełatwy do rozwiązania w skali obiektu, a potęguje się niezmiernie w przypadku historycznego miasta. Miasto historyczne jest bowiem bardzo złożonym organizmem, który trudno przedstawić jako sumę składowych. Zatem zbudowanie analitycznego modelu, który tworzą składowe opisujące różne aspekty miasta, jest zawsze uproszczeniem rzeczywistości, które ją zubaża i ogranicza. Jednak w konserwacji zabytków - podobnie jak w innych naukach, nie ma innej metody; trzeba stworzyć model sprowadzający zabytek do składowych, które potrafimy identyfikować i analizować.

Kluczowym zadaniem analitycznym w ochronie miast historycznych jest więc identyfikacja tworzących je składowych. Ważne jest przy tym przyjęcie właściwego poziomu szczegółowości składowych tworzących model miasta - ma on być jeszcze operacyjny (można nad nim zapanować), a jednocześnie odzwierciedlać złożoność historycznego miasta.

Specyfika działania konserwatorskiego, które ma na celu ochronę elementów zabytkowych, sprawia, że punktem wyjścia do stworzenia modelu historycznego miasta powinny być wartości. Zabytkowe wartości konstytuują bowiem ochronę zabytków. Ochrona zabytku polega więc na ochronie zabytkowych wartości - to wynika m.in. z ustawowej definicji zabytku i z bardzo wyraźnego ukierunkowania współczesnej teorii konserwatorskiej. Dlatego też identyfikacja zabytku i uzasadnienie jego ochrony powinny być oparte na zabytkowych wartościach.

Takie podejście jest fundamentem ochrony najcenniejszej grupy zabytków, czyli dóbr Światowego Dziedzictwa UNESCO. Cały system Światowego Dziedzictwa jest zbudowany na pojęciu „wyjątkowej uniwersalnej wartości”. Dlatego stworzono metodologię wskazywania tej wartości oraz określono warunki, które musi spełniać reprezentujące je dobro. W efekcie w liczących setki stron dokumentacjach dóbr nominowanych na Listę Światowego Dziedzictwa najważniejsze jest krótkie

\footnotetext{
3 Analizę przemian paradygmatu ochrony dziedzictwa omawia Gregory Ashworth w tekstach - Paradygmaty i paradoksy planowania przyszłości, [w:] G. Ashworth, Planowanie przyszłości, MCK, Kraków 2015, ss.21-142.

4 Szeroką panoramę współczesnych poglądów na temat roli wartościowania w rozumieniu i analizie dziedzictwa przedstawiają m.in. publikacje: Values and Criteria in Heritage Conservation, (praca zbiorowa), Edizioni Palistampa, Firence, 2008; Wartościowanie zabytków architektury (praca zbiorowa)), PKN ICOMOS, Warszawa Lublin, 2013; Systemy wartościowania dziedzictwa. Stan badań i problemy (praca zbiorowa), PKN ICOMOS, Warszawa Lublin, 2015.

5 Analizę pojęcia ouv, jego znaczenie, transformacje w czasie oraz charakterystykę wykorzystania w nominowaniu dóbr na Listę Światowego Dziedzictwa UNSCO przedstawia publikacja: The World Heritage List. What is OUV?, seria "Monuments and Sites", t.VI, ICOMOS International, Paris, 2008.
} 
Orzeczenie o Wyjątkowej Uniwersalnej Wartości. Orzeczenie zawiera opis wartości ouv, wskazanie kryteriów jej uznania, ocenę autentyzmu, integralności i stanu zarządzania. Wszystkie te elementy służą wykazaniu, że zabytek uznany za Światowe Dziedzictwo reprezentuje wartość ouv, i że jest ona należycie chroniona. Podobna zasada jest fundamentem polskiego systemu ochrony zabytków - celem ochrony zabytku jest zachowanie wartości, ze względu na które zyskał on ten status.

Jednak teoria konserwatorska nie opracowała modelu pokazującego jak należy analitycznie ustalać reprezentację wartości przez elementy zabytku (materialne lub niematerialne). W polskiej praktyce konserwatorskiej nie został nawet wdrożony model analizowania i określania wartości zabytku'. Konserwatorzy nie dokonują kompleksowych analiz zabytku, gdyż ich praca polega na reagowaniu na jednostkowe zagrożenia, opiniowaniu projektów przekształceń i inwestycji. Są to działania na zasadzie: akcja - reakcja. W polskim systemie ochrony zabytków o formie ich zachowania decydują bowiem przede wszystkim ich właściciele i użytkownicy, kierując się generalnie swoimi potrzebami użytkowymi. To określa miejsce służby konserwatorskiej i skalę jej zaangażowania. W konsekwencji narzuca zakres analizy wartości zabytku.

Inaczej w założeniu jest w systemie Światowego Dziedzictwa UNESCO, gdzie już na etapie opracowania dokumentacji nominacyjnej trzeba przeanalizować i wykazać wartość zgłaszanego zabytku. W systemie tym została wprawdzie opracowana metoda określania wartości zabytku, jednak nie ustalono sposobu ich powiązania $\mathrm{z}$ materialnym obiektem czy zespołem. Zapisy dotyczące tzw. atrybutów problemu tego nie rozwiązują w sposób zadawalający ${ }^{7}$. Dlatego $\mathrm{w}$ praktyce konserwatorzy odpowiedzialni za poszczególne obiekty - zarówno w dobrach Światowego Dziedzictwa jak i polskim systemie ochrony - muszą ten problem rozwiązywać indywidulanie. W oparciu o swoje doświadczenia i rozumienie zabytku, intuicyjnie określają materialną reprezentację wartości zabytku.

Taki stan rzeczy nie powinien być jednak kontynuowany, gdyż problem reprezentacji wartości przez materialnie istniejący zabytek jest coraz poważniejszy. Obecnie nie można już bowiem uznać, że konserwator powinien chronić zabytek przed przekształceniami. Nawet w systemie Światowego Dziedzictwa uznaje się, że zabytki powinny być chronione i użytkowane zgodnie z potrzebami szerokich grup interesariuszy. W praktyce ochrona zabytku polega więc na określaniu zakresu przekształceń i kontrolowaniu tego procesu.

6 Systemowe wprowadzenie wartościowania do zabytkowej dokumentacji w Polsce może dokonać się poprzez wdrożenie Karty Oceny Wartości Zabytku, która jest opracowywana w ramach Krajowego Programu Ochrony Zabytków przez zespół działający w Narodowym Instytucie Dziedzictwa. Karta ma być opracowana w roku 2022 i sprawdzona na grupie wybranych obiektów. Systemowa ocena wartości zabytku powinna poprzedzać jego wpisanie do rejestru zabytków, a jej elementy powinny być wykorzystanie w uzasadnieniu decyzji o wpisaniu do rejestru.

7 Analiza pojęcia „atrybutów”, w tym niejednoznaczność ich użycia w systemie Światowego Dziedzictwa przedstawia publikacja: B. Szmygin, Atrybuty wyjątkowej uniwersalnej wartości, [w:] Wyjątkowa Uniwersalna Wartość a monitoring Dóbr Światowego Dziedzictwa, PKN ICOMOS, Warszawa 2011, ss. 60-69. 
We współczesnych konserwatorskich tekstach doktrynalnych termin „konserwacja” ujmuje się inaczej niż przez ostatnie stulecie ${ }^{8}$. W przeszłości konserwacja zabytku była rozumiana jako działania służące zachowaniu jego historycznej formy i substancji (Karta Wenecka). Tymczasem obecnie konserwacja to wszelkie działania dokonywane przy obiektach zabytkowych. Dlatego analiza poprzedzająca działania konserwatorskie powinna określić elementy, które należy bezwzględnie chronić. To jednak również oznacza, że pozostałe elementy mogą być przekształcone. Konserwator powinien określić granice i formy tych przekształceń.

Wdrażanie takiego podejścia wymaga szczególnej ostrożności w miastach historycznych, ze względu na skalę działania i rozległe konsekwencje waloryzacji (wynikających z niej działań). Dlatego tak odpowiedzialnym zadaniem jest określenie składowych tworzących model historycznego zespołu. Składowe te trzeba zidentyfikować i przypisać im odpowiednią wartość.

W przypadku dóbr wpisanych na Listę UNESCO jedna strona tego równania jest już określona - wartości są formalnie zdefiniowane w dokumentacji przyjętej przez Komitet Światowego Dziedzictwa. Wartości te nie mogą być naruszone. Wartościom trzeba przypisaćich reprezentację - to druga strona równania. To zadanie jest podstawą opracowania Planów Zarządzania dla dóbr wpisanych i kandydujących na Listę UNESCO.

Dobrym przykładem ilustrującym rozwiązanie tego problemu są analizy służące opracowaniu Planu Zarzadzania dla centrum Krakowa, pierwszego w Polsce i na świecie zespołu miejskiego wpisanego na Listę Światowego Dziedzictwa ${ }^{10}$. Dla staromiejskiego zespołu w Krakowie nie opracowano wcześniej takiego dokumentu, dlatego wszystkie analizy potrzebne dla jego stworzenia są wykonywane po raz pierwszy.

Punktem wyjścia było oczywiście określenie wartości Krakowa na podstawie oficjalnych dokumentów zaakceptowanych przez Komitet Światowego Dziedzictwa UNESCO (jako podstawa wpisu). Analiza była przede wszystkim skoncentrowana na Orzeczeniu Wyjątkowej Uniwersalnej Wartości. Analizowano ten dokument w wersji przyjętej przez Komitet Światowego Dziedzictwa w 2016 roku, gdyż dokumentacja sporządzona w 1978 roku jeszcze tych zapisów nie zawierała ${ }^{11}$.

8 Wszechstronna analiza zmian związanych ze zmianą paradygmatu ochrony dziedzictwa została przedstawiona w zbiorowej monografii: Conservation Turn - Return to Conservation. Tolerance for Change, Limits of Change, Edizioni Polistampa, Firenze 2012.

9 Przegląd tradycyjnych teorii na temat ochrony zabytków zawiera praca: Krawczyk J., Nazwać, żeby ocalić. Klasycy myśli konserwatorskiej wobec reliktów przeszłości, Wydawnictwa Naukowe UMK, Toruń 2020.

10 Plan Zarzadzania historycznego zespołu w Krakowie opracowuje zespól w składzie: B.Szmygin, J. Purchla, A. Siwek, M. Wosińska, M. Wosiński. Realizacja Planu Zarzadzania wraz z konsultacjami i monitoringiem wdrażania obejmuje okres 3 lat (2021-2023).

11 Komitet Światowego Dziedzictwa zalecił aby dla dóbr, które nie miały orzeczeń określających wartość ouv opracować tzw. orzeczenia retrospektywne. Orzeczenia retrospektywne opracowano mając na uwadze stan dóbr (ich wartość i elementy) zgodnie ze stanem istniejącym w czasie ich wpisywania na Listę UNESCO. Orzeczenia retrospektywne zostały oficjalnie przyjęte przez Komitet Światowego Dziedzictwa (procedura podobna jak w przypadku orzeczeń nowych dóbr wpisywanych na Listę UNESCO). 
Z Orzeczenia zostały wybrane wszystkie zapisy, które można interpretować jako określające wartość zespołu. Z niewielkiego tekstu wybrano szereg sformułowań, które w sumie tworzą opis Wyjątkowej Uniwersalnej Wartości Krakowa. Wszystkie te zapisy potraktowano jako jedną stronę wspomnianego równania służącego powiązaniu wartości z ich materialną reprezentacją ${ }^{12}$.

Drugim działaniem powinno być zidentyfikowanie materialnych i niematerialnych składowych Krakowa, które reprezentują wybrane z Orzeczenia wartości. Jednak wybieranie składowych miasta bez porządkującego modelu byłoby trudne i chaotycznie. Dlatego został wprowadzony pewien szkielet/ruszt, w którym składowe historycznego miasta są ujęte w czterech zasadniczych grupach.

Zostały określone następujące grupy składowych miasta:

- obiekty architektoniczne (identyfikowane jako dzieła - całości mające indywidualną wartość)

- charakterystyczne cechy zabudowy (nadające tożsamość historycznemu zespołowi)

- składowe urbanistyczne (najcenniejsze i charakterystyczne)

- składowe niematerialne (najcenniejsze i charakterystyczne)

Każda z wyszczególnionych grup powinna być powiązana z odpowiednimi zapisami wartości wymienionymi w Orzeczeniu WUW.

Jednak do planu ochrony i zarzadzania miasta konieczne jest pogłębienie analizy - wskazanie konkretnych elementów. Dlatego w każdej z 4 grup zostały zidentyfikowane podgrupy, czyli zbiory elementów o podobnej charakterystyce. W przypadku pierwszej grupy - „obiekty architektoniczne" w Krakowie o uznanej wartości, zidentyfikowano 5 zbiorów. Są to: obiekty mieszkalne, religijne, publiczne, obronne i zespół wawelski. W każdej z czterech grup określono po kilka takich podgrup/zbiorów, w oparciu o analizę krakowskiego zespołu.

W kolejnym kroku dokonano identyfikacjikonkretnych elementów należących do poszczególnych zbiorów. Na przykład w przypadku „obiektów architektonicznych” przyjęto, że w krakowskim zespole obiekty o istotnej wartości zostały już zidentyfikowane i wpisane do rejestru zabytków. Zatem w tej grupie będzie to 5 zbiorów obiektów wpisanych do rejestru. Najmniejsze zbiory (fortyfikacje) liczą po kilka pozycji, największe (mieszkalne) po kilkadziesiąt. Całościową analizę przedstawia tabela pokazująca identyfikację 5 podgrup obiektów tworzących grupę „obiekty architektoniczne", powiazanie ich z konkretnymi obiektami zespołu w Krakowie oraz odniesienie do sformułowań w Orzeczeniu WUW1 ${ }^{13}$.

12 Metodologia oceny wartości zabytku i powiązania ich z materialną reprezentacją została przedstawiony w publikacji: Szmygin B., Fortuna-Marek A., Siwek A., Assessing the Values of Heritage in SV System: the Method and Examples of Use, Lublin 2018.

13 Tabele powiazania wartości zespołu w Krakowie z ich materialną reprezentacją opracował dr. A. Siwek z Narodowego Instytutu Dziedzictwa, członek zespołu opracowującego Plan Zarządzania Krakowa. 
Tab. 1 Analityczny model wartości i składowych historycznego zespołu miejskiego. Dzieła architektury

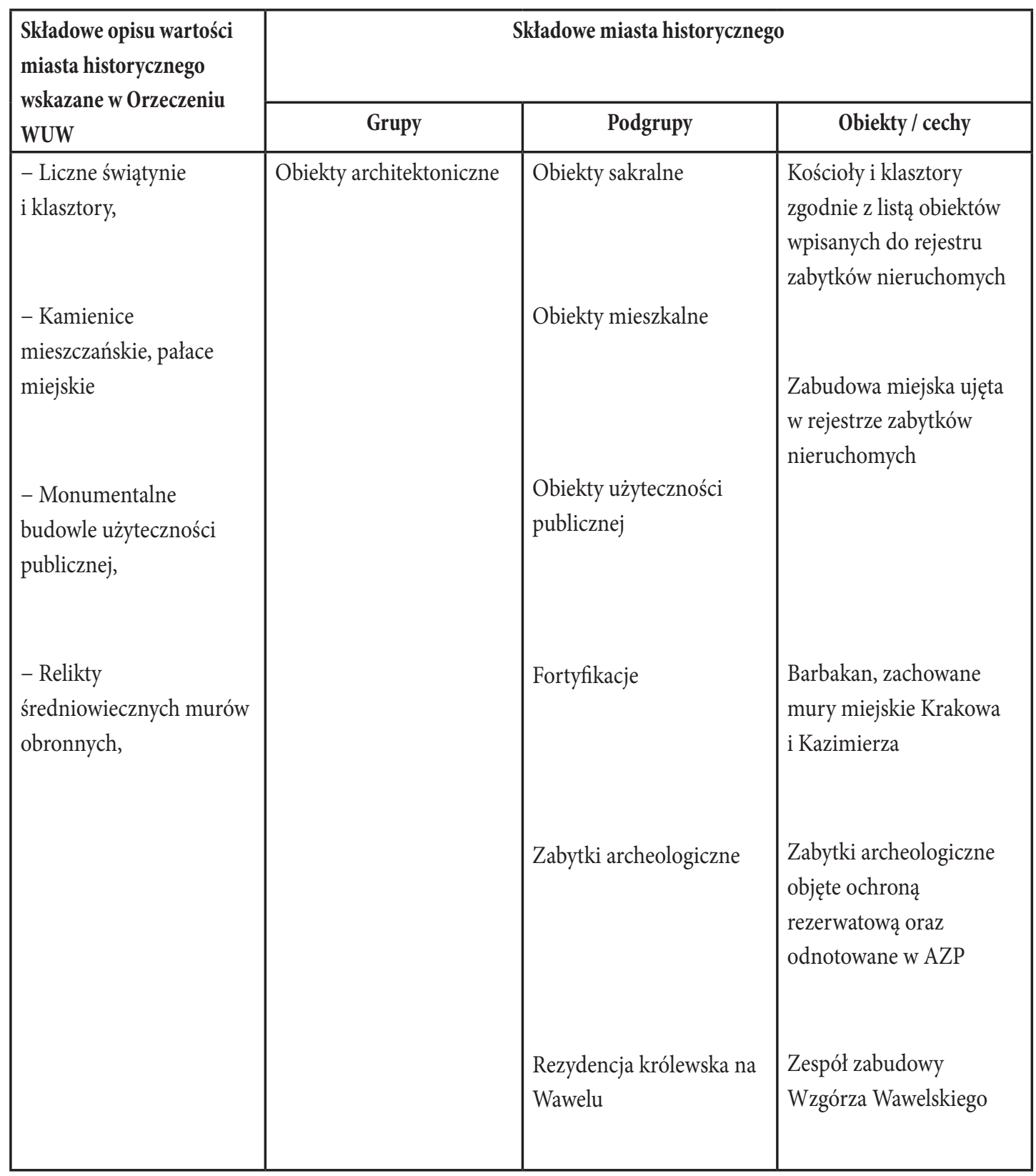


W podobny sposób rozpisano i przeanalizowano każdą z 4 grup składowych tworzących wartość staromiejskiego zespołu UNESCO w Krakowie. W efekcie każdej wartości zidentyfikowanej w Orzeczeniu WUW zostały przypisane konkretne zbiory elementów (obiektów) lub cech, które je reprezentują, i które powinny być przedmiotem ochrony ${ }^{14}$.

Przedstawiony model analizy, wiążący wartości z ich reprezentacją, nie prowadzi oczywiście w sposób mechaniczny do wskazań jak chronić i zarządzać zespołem staromiejskim. Nie ma też wątpliwości, że model nie ujmuje w pełnio złożoności miasta i jego wartości, na przykład całego obszaru objętego pojęciem genius loci. Tym niemniej pozwala na analityczne i całościowe postrzeganie miasta, potrzebne do planowania i monitorowania działań konserwatorskich. Pozwala na lepsze zrozumienie konsekwencji, jakie mają wszelkie działania dotyczące składowych miasta. Dlatego taka analiza jest punktem wyjścia i odniesienia dla planów ochrony i zarzadzania miastami historycznymi.

Przeprowadzone analizy pozwalają sformułować pewne założenia do działań konserwatorskich i zarządczych w miastach historycznych:

1. Wartości zabytkowe miasta historycznego są reprezentowane przez materialne i niematerialne nośniki, które mogą być określone analitycznie; (oczywiście) określenie nośników wartości ma charakter upraszczający i przybliżony.

2. Celem ochrony i zarządzania miasta historycznego z konserwatorskiego punktu widzenia jest przede wszystkim ochrona jego zabytkowych wartości; (dlatego) ochrona i zarządzanie powinny być realizowane przede wszystkim przez działania dotyczące składowych będących nośnikami wartości miasta historycznego.

3. Określeniu składowych, które są nośnikami wartości miasta historycznego, służy analityczny model wartości i składowych miasta historycznego; model łączy opis wartości ze składowymi miasta historycznego.

Model wyróżnia trzy poziomy analizy składowych - 4 grupy składowych (mają charakter uniwersalny), odpowiednie podgrupy składowych charakteryzujące dane miasto, konkretne obiekty/cechy będące nośnikami wartości w danym mieście historycznym.

4. Analiza zabytkowego obiektu/obszaru oparta o model pozwalający połączyć wartości z ich reprezentacją (materialną i niematerialną), powinna być podstawą dokumentów formułujących politykę i plany konserwatorskie wobec zabytku - np. Plany Zarządzania, Gminne Programy Opieki nad Zabytkami, Gminne Programy Rewitalizacji (dla obszarów zabytkowych).

14 Wszystkie tabele przedstawia artykuł: Szmygin B., Siwek A., Fortuna-Marek A., Model reprezentacji wartości dobra Światowego Dziedzictwa UNESCO dla miasta historycznego, „Ochrona Zabytków”, nr 2/2021, Warszawa 2021 (w druku). 


\section{Bibliografia}

Ashworth G., Paradygmaty i paradoksy planowania przyszłości, [w:] G. Ashworth, Planowanie przyszłości, MCK, Kraków 2015, ss. 21-142.

Bandarin F., van Oers R., The Historic Urban Landscape. Managing Heritage in an Urban Century, Wiley-Blackwell, 2012.

Conservation Turn - Return to Conservation. Tolerance for Change, Limits of Change, Edizioni Polistampa, Firenze 2012.

Council of Europe Framework Convention on the Value of Cultural Heritage for Society (Faro,27.X.2005); http://conventions.coe.int/Treaty/EN/Treaties/Html/199.html

Krawczyk J., Nazwać, żeby ocalić. Klasycy myśli konserwatorskiej wobec reliktów przeszłości, Wydawnictwa Naukowe UMK, Toruń 2020.

Systemy wartościowania dziedzictwa. Stan badań i problemy (praca zbiorowa), PKN ICOMOS, Warszawa Lublin, 2015.

Szmygin B., Atrybuty wyjątkowej uniwersalnej wartości, [w:] Wyjątkowa Uniwersalna Wartość a monitoring Dóbr Światowego Dziedzictwa, PKN ICOMOS, Warszawa 2011, ss. 60-69.

Szmygin B., Fortuna-Marek A., Siwek A., Assessing the Values of Heritage in SV System: the Method and Examples of Use, Lublin 2018.

Szmygin B., Siwek A., Fortuna-Marek A., Model reprezentacji wartości dobra Światowego Dziedzictwa UNESCO dla miasta historycznego, „Ochrona Zabytków”, nr 2/2021, Warszawa 2021 (w druku).

The World Heritage List. What is OUV?, seria "Monuments and Sites", t.VI, ICOMOS International, Paris, 2008.

Values and Criteria in Heritage Conservation, (praca zbiorowa), Edizioni Palistampa, Firence, 2008.

Wartościowanie zabytków architektury (praca zbiorowa)), PKN ICOMOS, Warszawa Lublin, 2013. 